\title{
Efficacy and safety of topical eprinomectin to control Myocoptes musculinus infestation in mice
}

\author{
Eficácia e segurança da eprinomectina tópica para controlar a infestação \\ Myocoptes musculinus em camundongos \\ Luisa Rambozzi ${ }^{1 *}$; Luca Rossi ${ }^{1}$; Anna Rita Molinar Min ${ }^{1}$; Luca Osella ${ }^{1}$; Sergio Bellardi ${ }^{1}$; \\ Roberto Marchetti²; Paolo Pollicino ${ }^{1}$
}

\begin{abstract}
${ }^{1}$ Dipartimento di Scienze Veterinarie, Scuola di Agraria e Medicina Veterinaria, Università di Torino - UNITO, Grugliasco, Torino, Italy

${ }^{2}$ Veterinary Practitioner, Caselle, Torino, Italy.
\end{abstract}

Received September 12, 2013

Accepted November 1, 2013

\begin{abstract}
Myocoptes musculinus is the most common fur mite identified among laboratory mice; infested mice, in addition to dermatological signs, may also be prone to secondary infections, affecting the outcome of a research trial. This trial was conducted in order to assess the safety and efficacy of a single topical administration of eprinomectin $(5 \mathrm{mg} / \mathrm{kg}$ BW) in a naturally infested laboratory mice colony. A safety trial was conducted on 20 uninfested pregnant females assigned to two groups, receiving eprinomectin and mineral oil, respectively. The mice were examined daily for signs of illness or toxicity; nests were individually weighted at 21 and 28 days postpartum. No acute toxicity was observed, all treated females gave full term delivery and number and mean weight of newborns ranged in the physiological values. To evaluate the efficacy, 20 naturally infested non-pregnant females were divided into two groups, treated as in the safety trial. Animals were observed daily for 15 min until 21 days post-treatment (DPT) and a "pruritus index" (PI: scratching and gnawing acts/mouse/min) was calculated. Pelage examination was performed on DPT 7, 14, 21 and 50. The "PI" was significantly lower in the treated group and mites were eradicated from all infested animals. A single topical administration of eprinomectin at a (high) dosage of $5 \mathrm{mg} / \mathrm{kg} \mathrm{BW}$ was safe and effective to control M. musculinus in mice.
\end{abstract}

Keywords: Mite, ectoparasite control, mouse.

\section{Resumo}

Myocoptes musculinus é o ácaro de pele mais comum identificado entre camundongos de laboratório. Camundongos infestados, além de sinais dermatológicos, também podem ser propensos a infecçôes secundárias, interferindo no resultado de um ensaio de pesquisa. Este estudo foi realizado para avaliar a segurança e eficácia de uma única administração tópica de eprinomectina ( $5 \mathrm{mg} / \mathrm{kg} \mathrm{PV}$ ) em uma colônia de camundongos de laboratório naturalmente infestada. Um estudo de segurança foi realizado em 20 fêmeas prenhes sadias, divididas em dois grupos, recebendo eprinomectina e óleo mineral, respectivamente. Os camundongos foram examinados diariamente para detectar quaisquer sinais da doença ou toxicidade; camundongos recém-nascidos foram pesados individualmente aos 21 e 28 dias pós-parto. Nenhuma toxicidade aguda foi observada. Todas as fêmeas tratadas chegaram ao parto, o número e peso dos recém-nascidos variaram dentro de parâmetros fisiológicos. Para avaliar a eficácia, 20 camundongos não prenhes, naturalmente infestados, foram divididos em dois grupos: tratado e grupo controle náo tratado. Os animais foram observados diariamente durante 15 minutos até os 21 dias pós- tratamento (DPT) e um índice de prurido (IP) arranhóes e ato de roer / camundongo / min) foi calculado. Exame da pelagem foi realizado em DPT 7, 14, 21 e 50 . O IP foi significativamente menor no grupo tratado, e os ácaros foram erradicados de todos os animais infestados. Uma única administraçáo tópica de eprinomectina, na dose de $5 \mathrm{mg} / \mathrm{kg}$ de peso corporal, foi segura e eficaz no controle de M. musculinus em camundongos.

Palavras-chave: Ácaro, controle ectoparasita, camundongo.

\footnotetext{
${ }^{*}$ Corresponding author: Luisa Rambozzi

Dipartimento di Scienze Veterinarie, Università di Torino - UNITO,

Via Leonardo da Vinci, 44, 10095, Grugliasco, TO, Italy

e-mail: luisa.rambozzi@unito.it
} 
Myocoptes musculinus is the most common fur mite identified among laboratory mice (FOX et al., 2002) and it has been associated with excessive pruritus; alopecia and a range of conditions, including ulcerative dermatitis, hypersensitivity dermatitis, and pyoderma can also develop (FOX et al., 2002, 2007). Infested mice may also be prone to secondary infections, reduced life span, and decrease of body weight (WELTER et al., 2007).

A number of published studies have reported successful colony eradication of fur mites with oral ivermectin (CONOLE et al., 2003; RICART ARBONA et al., 2010), oral moxidectin (POLLICINO et al., 2008), injectable ivermectin (WING et al., 1985) and topical parasiticides as selamectin (GONENC et al., 2006; MOOK; BENJAMIN, 2008), ivermectin (BAUMANS et al., 1988; MOOK; BENJAMIN, 2008) and moxidectin (PULLIUM et al., 2005; MOOK; BENJAMIN, 2008).

Here we reported the effectiveness and safety of a single topical administration of eprinomectin to control Myocoptes musculinus infestation in a naturally infested laboratory mice colony.

In January 2012, mice exhibiting excessive pruritus as the only clinical sign were signaled at a laboratory animal facility of the University of Turin, Italy.

The laboratory animal facility housed approximately 2700 adult male and female conventional and transgenic mice (FVB/NCrl, C57, BalbC/a and 129/OLA).

The animal facility, including the environmental conditions (12-h light: 12 -h dark cycle, RT $21^{\circ} \mathrm{C} \pm 1{ }^{\circ} \mathrm{C}$ and RH 55\% $\pm 5 \%$ ) and animal housing were within the requirements established by European and National laws (86/609/CEE and DL 116/92). Animals housed in same-sex groups of 10 in transparent conventional polycarbonate cages (Tecnoplast, Buggirate, Italy) with isolator tops and corncob bedding, were fed rodent chow (4RF18GLP Rodent Diet, Mucedola Srl, Settimo Milanese, Italy) and provided with tap water ad libitum. Fur samples were obtained from 50 symptomatic animals, randomly selected in 50 different cages.

For pelage test, a $2 \times 8 \mathrm{~cm}$ of clear scotch tape $\left(\mathrm{Scotch}^{\otimes} \mathrm{Crystal}\right.$, $3 \mathrm{M}^{\mathrm{tm}}$, Milan, Italy) was thoroughly rubbed on the head, neck, back, ventral region of the thorax and abdomen of each mouse. The tape was then affixed to a glass microscope slide with a drop of oil and examined for ectoparasites at 40x magnification.

A pelage sample was also cultured on Mycobios-selective agar (Biolife Italiana Srl, Milan, Italy) to exclude concomitant dermatophytosis as the cause of the dermatological lesions.

Pelage examination revealed Myocoptes musculinus adult fur mites and/or larvae and/or eggs in all the 50 mice examined. No other ectoparasites were detected, and all cultures were negative for dermatophytes.

Since the lifecycle of $M$. musculinus ranges from 8 to 14 days, with eggs hatching in 5 days (FOX et al., 2002), and because of its surface-feeding nature, in the effort to develop a simple and rapid one-time treatment protocol, a single topical administration of eprinomectin was tested.

A preliminary safety trial was conducted on $20 \mathrm{FVB} / \mathrm{NCrl}$ uninfested pregnant females (term delivery at $24 \mathrm{~h}-10$ days); animals were isolated in individual cages and randomly assigned to one of two experimental groups of 10. Group A received pour-on eprinomectin (Eprinex ${ }^{\oplus}$ Pour-on, Merial Italia SpA, containing $0.5 \%$ active ingredient) at the approximate dosage of $5 \mathrm{mg} / \mathrm{kg}$
BW $(27 \mu \mathrm{L} /$ mouse) $)$ Eprinex ${ }^{\oplus}$ Pour-on was topically applied to the skin in a single spot at the base of the neck. Control mice (Group B) received $27 \mu \mathrm{L}$ mineral oil on the same day. Mice were examined daily for any signs of illness or toxicity, including neurological abnormalities; moreover, to monitor the growth, nests were individually weighted at 21 and 28 days post partum.

No acute toxicity was observed in 10 treated mothers, and gross behavior and appetite were not affected. All treated females gave full term delivery and number of newborns ranged from 4 to 7 , for a total of 58 mice. The mean weight of newborns was $10.8+0.3 \mathrm{~g}$ at the age of 3 weeks, and $16.1+0.4 \mathrm{~g}$ at the age of 4 weeks, ranging in the physiological values of the corresponding line (Charles River Laboratories, 2004). No statistical differences were recorded in controlled mice, regarding the number of newborns (a total of 60 , ranging from 4 to 8 ) and the mean weight 11.5 grams $+0.5 \mathrm{~g}$ at the age of 3 weeks and 16.8 grams $+0.3 \mathrm{~g}$ at 4 weeks.

In parallel, an efficacy trial was carried out on 20 naturally infested non-pregnant females, which were divided into Groups C and D, based on detection of fur mites and/or their eggs. A third group (Group E) of 10 uninfested mice served as untreated control. On Day 0, Group C received pour-on eprinomectin (same formulation, application and dosage as in the safety trial); positive control mice (Group D) and uninfested mice (Group E) received $27 \mu \mathrm{L}$ mineral oil on the same day. Each group was observed daily for $15 \mathrm{~min}$, during the 3 days of pre-treatment up to 21 days post-treatment; observation involved evaluation of clinical signs of infestation such as scratching, alopecia, rough coat, presence of scabs or sores, and trauma to ears or skin or no outward clinical signs of infestation.

All scratching and gnawing acts were recorded and a "pruritus index" (acts/mouse/min) was calculated, according to Jensen et al. (2002) and Loewenstein et al. (2006). The presence/absence of mites and/or their eggs was estimated in all mice within Groups $\mathrm{C}$ and $\mathrm{D}$ by double (ventral and dorsal) pelage tape test on experimental days 7,14, 21 and 50. Numbers of scratching and gnawing acts recorded in Groups C and D were compared by the Student's $t$-test.

No side effects or signs of illness were observed in any of the treated animals. Treatment resulted in clinical improvement after the first week following Eprinex ${ }^{\oplus}$ Pour-on administration. After the first day of post-treatment a significant decrease $(\mathrm{P} \leq 0.001)$ of scratching and gnawing acts was recorded (Figure 1). On day 7 pelage tape tests showed that all mites were eliminated; only empty and unviable desiccated eggs (Figure 2) were observed in the treated group on days 7, 14 and 21 (in 70\%, 90\% and 20\% of mice, respectively), and no egg or mite on day 50 .

Positive control mice showed no clinical improvement compared to the treated group, the "pruritus index" was significantly (from $\mathrm{P} \leq 0.01$ to $\leq 0.001$ ) higher in all three experimental weeks.

At the end of the trial positive control mice were treated.

Fur mites infestations in research colonies remain a constant management challenge. Fur mites have been reported to interfere with established research models by directly potentiating allergictype hypersensitivity reactions (MORITA et al., 1999), indirectly interfering with normal immune responses to other (WELTER et al., 2007) and have been shown to provoke a Th2 immune response 


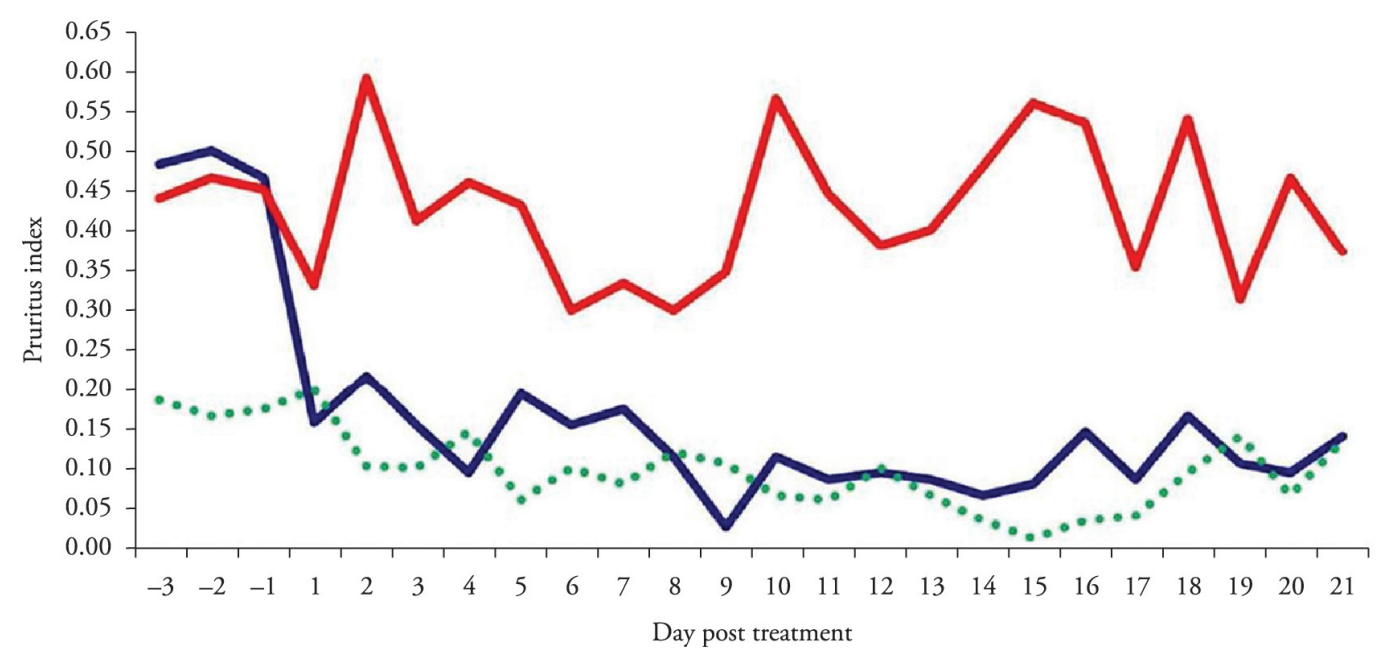

Figure 1. "Pruritus Index" (acts/animal/min) recorded for each experimental group (dotted line: control health group; blue line: infested treated group; red line: infested untreated control group).

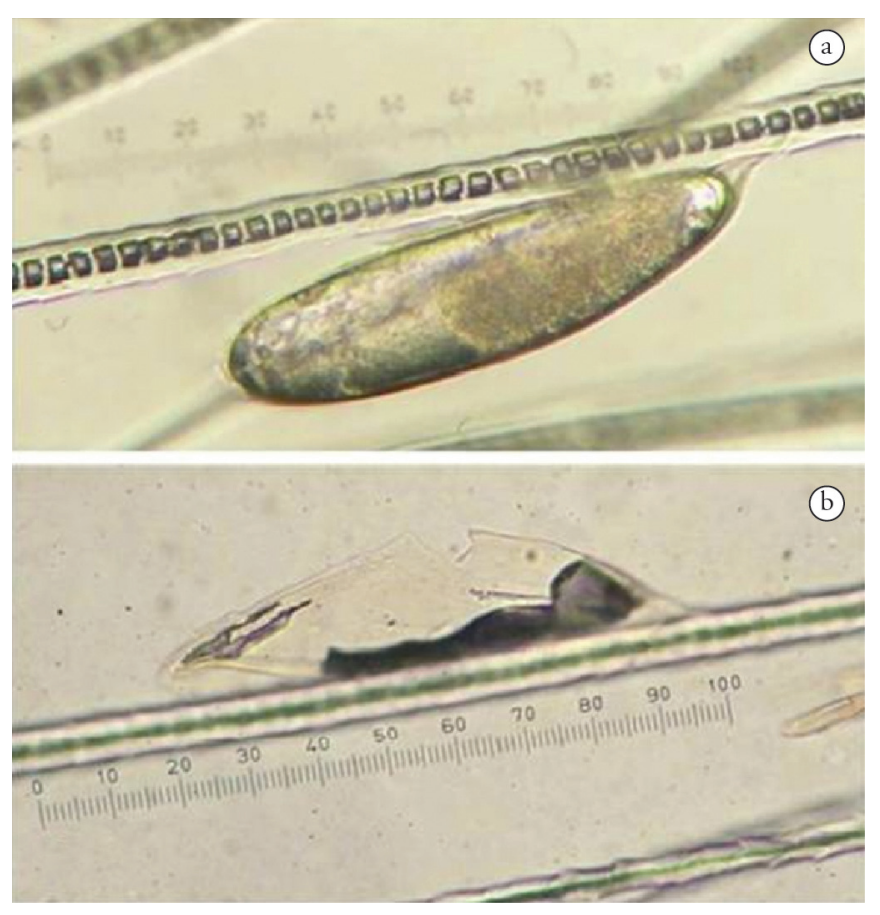

Figure 2. Myocoptes musculinus egg (40x) on mouse's hair. Viable egg before treatment (a) and unviable egg at 14 days post treatment with topical eprinomectin (b).

and elevate serum IgE (LALTOO et al., 1979; JUNGMANN et al., 1996).

In spite of the labor and time saving of oral administration in drinking water or food, a widespread acaricide treatment could be contraindicated due to the potential for adverse effects; for example, ivermectin and moxidectin, although effective against fur mites, can be lethal in neonatal pups and genetically modified mice with defective blood-brain barriers (SCHINKEL et al., 1994; SKOPETS et al., 1996); moreover, moxidectin was also associated to an episode of acute toxicosis and mortality after routine prophylactic treatment in two strains of mice (LEE et al., 2009).
Topical administration, even if it requires a more intensive labor, ensures accurate dosing of the single mouse and prevents inadvertent toxicosis.

Under the conditions of this study, the tested single-dosage had similar efficacy as the single-dosage topical treatment with moxidectin, which is a well recognized operator-friendly option for control and eradication of the fur mite in large colonies of laboratory mice.

A single topical administration of eprinomectin at a high dosage of $5 \mathrm{mg} / \mathrm{kg} \mathrm{BW}$ was safe and effective in the control of M. musculinus in mice.

\section{References}

Baumans V, Havenaar R, Van Herck H, Rooymans TP. The effectiveness of Ivomec and Neguvon in the control of murine mites. Lab Anim 1988; 22(3): 243-245. http://dx.doi. org/10.1258/002367788780746368

Charles River Laboratories. Technical report on FVB/NCrl mice. 2004. Available from: http://www.criver.com/SiteCollectionDocuments/FVB. pdf.

Conole J, Wilkinson MJ, McKellar QA. Some observations on the pharmacological properties of ivermectin during treatment of a mite infestation in mice. Contemp Top Lab Anim Sci 2003; 42(4): 42-45.

Fox JG, Andersen LC, Loew FM, Quimby FW. Laboratory animal medicine. New York: Academic Press; 2002.

Fox JG, Barthold SW, Davisson MT, Newcomer CE, Quimby FW, Smith AL. The mouse in biomedical research. St Louis: Academic Press; 2007.

Gonenc B, Sarimehmetoglu HO, Ica A, Kozan E. Efficacy of selamectin against mites (Myobia musculi, Mycoptes musculinus and Radfordia ensifera) and nematodes (Aspiculuris tetraptera and Syphacia obvelata) in mice. Lab Anim 2006; 40(2): 210-213. http://dx.doi. org/10.1258/002367706776319105

Jensen JCE, Nielsen LH, Arnason T, Cracknell V. Elimination of mange mites Sarcoptes scabiei var. suis from two naturally infested danish 
sow herds using a single injection regime with doramectin. Acta Vet Scand 2002; 43(2): 75-84. http://dx.doi.org/10.1186/1751-0147-43-75

Jungmann P, Freitas A, Bandeira A, Nobrega A, Coutinho A, Marcos $\mathrm{MA}$, et al. Murine acariasis. II. Immunological dysfunction and evidence for chronic activation of Th-2 lymphocytes. Scand J Immunol 1996; 43(6): 604612. http://dx.doi.org/10.1046/j.1365-3083.1996.d01-259.x

Laltoo H, Van Zoost T, Kind LS. IgE antibody response to mite antigens in mite-infested mice. Immunol Commun 1979; 8(1): 1-9.

Lee VK, Tiwary AK, Sharma-Reddy P, Lieber KA, Taylor DK, Mook DM. Moxidectin toxicity in senescence-accelerated prone and resistant mice. Comp Med 2009; 59(3): 227-233.

Loewenstein M, Ludin A, Schuh M. Comparison of scratching behaviour of growing pigs with sarcoptic mange before and after treatment, employing two distinct approaches. Vet Parasitol 2006; 140(3-4): $334-$ 343. http://dx.doi.org/10.1016/j.vetpar.2006.04.001

Mook DM, Benjamin KA. Use of selamectin and moxidectin in the treatment of mouse fur mites. J Am Assoc Lab Anim Sci 2008; 47(3): 20-24.

Morita E, Kaneko S, Hiragun T, Shindo H, Tanaka T, Furukawa T, et al. Fur mites induce dermatitis associated with IgE hyperproduction in an inbred strain of mice, NC/Kuj. J Dermatol Sci 1999; 19(1): 37-43. http:// dx.doi.org/10.1016/S0923-1811(98)00047-4

Pollicino P, Rossi L, Rambozzi L, Farca AM, Peano A. Oral administration of moxidectin for treatment of murine acariosis due to Radfordia affinis.
Vet Parasitol 2008; 151(2-4): 355-357. http://dx.doi.org/10.1016/j. vetpar.2007.10.018

Pullium JK, Brooks WJ, Langley AD, Huerkamp MJ. A single dose of topical moxidectin as an effective treatment for murine acariasis due to Myocoptes musculinus. Contemp Top Lab Anim Sci 2005; 44(1): 26-28.

Ricart Arbona RJ, Lipman NS, Wolf FR. Treatment and eradication of murine fur mites: III. Treatment of a large mouse colony with ivermectincompounded feed. J Am Assoc Lab Anim Sci 2010; 49(5): 633-637.

Schinkel AH, Smit JJ, van Tellingen O, Beijnen JH, Wagenaar E, van Deemter L, et al. Disruption of the mouse mdr1a P-glycoprotein gene leads to a deficiency in the blood-brain barrier and to increased sensitivity to drugs. Cell 1994; 77(4): 491-502. http://dx.doi.org/10.1016/00928674(94)90212-7

Skopets B, Wilson RP, Griffith JW, Lang CM. Ivermectin toxicity in young mice. Lab Anim Sci 1996; 46(1): 111-112.

Welter A, Mineo JR, De Oliveira Silva DA, Lourenco EV, Vieira Ferro EA, Roque-Barreira MC, et al. BALB/c mice resistant to Toxoplasma gondii infection proved to be highly susceptible when previously infected with Myocoptes musculinus fur mites. Int J Exp Pathol 2007; 88(5): 325-335. http://dx.doi.org/10.1111/j.1365-2613.2007.00534.x

Wing SR, Courtney CH, Young MD. Effect of ivermectin on murine mites. J Am Vet Med Assoc 1985; 187(11): 1191-1192. 